\title{
PENGEMBANGAN SISTEM PENILAIAN KENAIKAN PANGKAT DOSEN PADA JURUSAN PENDIDIKAN TEKNIK ELEKTRO UNIVERSITAS NEGERI MAKASSAR
}

\author{
Ruslan $^{1}$, Edi Suhardi Rahman ${ }^{2}$, Dyah Vitalocca ${ }^{3}$ \\ ${ }^{1}$ Program Studi Pendidikan Teknik Elektro \\ ruslan.ft@unm.ac.id \\ ${ }^{2}$ Program Studi Teknik Elektro \\ edisuhardi@unm.ac.id \\ ${ }^{3}$ Program Studi Pendidikan Teknik Informatika dan Komputer \\ Dyah_vitalocca@unm.ac.id
}

\begin{abstract}
ABSTRAK
Penelitian ini bertujuan mengembangkan sistem informasi untuk pengelolaan berkas-berkas aktivitas akademik dosen di Jurusan Pendidikan Teknik Elektro, meliputi kegiatan tridharma perguruan tinggi dan penunjang. Selain mengelola berkas-berkas dosen, aplikasi ini juga mampu memberikan penyampaian kepada dosen yang bersangkutan tentang keterpenuhan kriteria untuk kenaikan jabatan fungsional dan pangkat akademik. Penelitian ini dilaksanakan pada Jurusan Pendidikan Teknik Elektro, Fakultas Teknik, Universitas Negeri Makassar dengan lama penelitian 8 (delapan) bulan. Penelitian ini menggunakan metode penelitian dan pengembangan. Model pengembangan menggunakan Waterfall, meliputi proses analisis kebutuhan, desain, implementasi, dan pengujian aplikasi. Produk penelitian ini adalah sebuah sistem informasi yang mampu mengelola berkas-berkas dosen terkait dengan tridarma perguruan tinggi dan penunjang. Selain itu sistem informasi ini mampu memberikan pesan kepada dosen yang bersangkutan apakah berkas-berkasnya telah mencukupi untuk kenaikan jabatan fungsional dan pangkat akademiknya. Aplikasi ini mampu untuk mengefektifkan proses tersebut dikarenakan semua dokumen telah ada di dalam sistem dan telah dipilah-pilah berdasarkan jenis kegiatannya. Hasil uji menunjukkan bahwa sistem informasi ini berfungsi dengan baik. Sistem mampu memberikan rekomendasi pada dosen tentang keterpenuhan kriteria untuk kenaikan jabatan fungsional dan pangkat akademik yang akan diajukannya.
\end{abstract}

Kata Kunci: Sistem Informasi, Penilaian Kenaikan Pangkat, Aktivitas Tridharma

\section{EVELOPMENT OF ASSESSMENT SYSTEM FOR LECTURER RANK AT THE DEPARTMENT OF ELECTRONIC ENGINEERING EDUCATION, MAKASSAR STATE UNIVERSITY}

\begin{abstract}
This study aims to develop an information system for managing files on academic activities of lecturers in the Department of Electrical Engineering Education, including university tridharma and supporting activities. In addition to managing lecturer files, this application is also able to provide submissions to the lecturers concerned about the fulfillment of the criteria for promotion to functional positions and academic ranks. This research was conducted at the Department of Electrical Engineering Education, Faculty of Engineering, Makassar State University with a research period of 8 (eight) months. This study uses research and development methods. The development model uses Waterfall, covering the process of needs analysis, design, implementation, and application testing. The product of this research is an information system that is able to manage lecturer files related to the tridharma of higher education and support. In addition, this information system is able to give a message to the lecturer concerned whether the files are sufficient for a functional promotion and academic rank. This application is able to streamline the process because all documents are already in the system and have been sorted based on the type of activity. The test results show that this information system is functioning properly. The system is able to provide recommendations to lecturers regarding the fulfillment of the criteria for the promotion of functional positions and academic ranks to be submitted.
\end{abstract}

Keyword: Information System, Rank Promotion Assessment, Tridharma Aktivitas Activities 


\section{PENDAHULUAN}

Dosen adalah pendidik profesional dan ilmuwan dengan tugas pokok mentransformasikan perkembangan dan menyebarkan ilmu dan seni teknologi melalui pendidikan, penelitian serta pengabdian masyarakat [1] dan dapat memiliki jabatan fungsional [2]. Untuk memperoleh jabatan fungsional, dosen wajib melakukan kegiatan Tri dharma perguruan tinggi yang terdiri dari pelaksanaan Pendidikan, penelitian, pengabdian dan unsur penunjang. Minimnya sosialisasi penghitungan angka kredit menjadi salah satu kendala dosen Ketika ingin mengajukan jabatan fungsional tertentu [3].

Selama ini pada Jurusan Pendidikan Teknik ELektro Fakultas Teknik Universitas Negeri Makassar, proses pengajuan kenaikan pangkat dosen mengikuti prosedur birokrasi dan banyak melibatkan banyak pihak. Hal ini merupakan salah satu kendala dikarenakan dokumen yang dibuat masih secara manual dan memungkinkan untuk terjadinya kehilangan arsip bahkan sampai rusak. Selain permasalahan tersebut, dosen juga belum memperoleh informasi mengenai waktu dan kecukupan angka kredit untuk memperoleh kenaikan jabatan fungsional dan pangkat akademik, sehingga masih banyak dosen yang lebih dari 2 tahun belum mengajukan kenaikan jabatan fungsional dan pangkatnya [4].

Untuk menyelesaikan permasalahan maka diperlukan sebuah sistem informasi untuk memudahkan dosen dalam mengelola kenaikan pangkat akademik dan jabatan fungionalnya. Pembuatan sistem ini merupakan salah satu solusi bagi dosen dikarenakan sistem yang dibuat mampu menyimpulkan bahwa dosen yang bersangkutan sudah memenuhi syarat untuk memperoleh kenaikan jabatan fungsional maupun pangkat akademik.

Pada penelitian ini pembanguan sistem informasi kenaikan jabatan fungsional dosen mengacu pada Pedoman Operasional Penilaian Angka Kredit Kenaikan Jabatan Akademik/Pangkat Dosen (PO 2019) ini merupakan penyempurnaan dari PO 2014. Mekanisme layanan dibuat dengan sistem online (daring) yang diharapkan dapat meningkatkan efisiensi layanan dan mendukung prinsip-prinsip penilaian [5].

Penelitian ini bertujuan untuk mengetahui hasil penerapan sistem infirmasi kenaikan jabatan fungsional dosen dalam mengatasi permasalahan perhitungan angka kredit dan kurangnya inisiatif dosen, serta dapat melakukan pengujian terhadap sistem informasi kenaikan jabatan fungsional dosen untuk mendapatkan sistem yang dapat berjalan dengan baik dan sesuai diharapkan.

\section{METODE PENELITIAN}

\section{A. Desain Penelitian}

Penelitian ini menggunakan pendekatan model waterfall pada pengembangan perangkat lunak. Model waterfall merupakan proses membangun perangkat lunak secara sekuensial dimana kemajuan dianggap jika proses semakin ke bawah (mirip dengan air terjun) melalui daftar tahapan yang harus dijalankan untuk keberhasilan membangun sebuah perangkat lunak komputer [6]. Model waterfall mendefenisikan secara berturut-turut fase yang harus diselesaikan secara bertahap dan pindah ke fase berikutnya hanya jika fase sebelumnya telah selesai [7]. Tahapan-tahapan motode penelitian yang digunakan dalam penelitian ini dalapt dilihat pada Gambar 1.

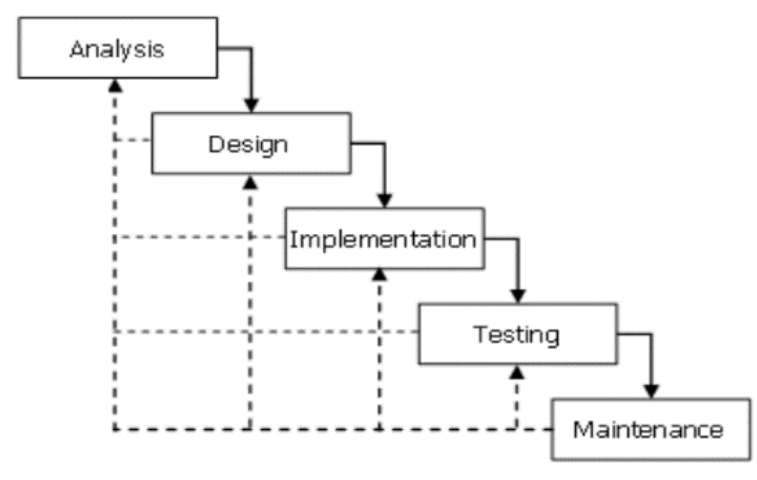

Gambar 1. The Waterfall Model

\section{B. Instrumen dan Pengumpulan Data}

Instrument yang digunakan dalam pengujian sistem ini adalah ISO. ISO 25010 menjadi standar pengujian international dalam penentuan kualitas perangkat lunak [8]. Pengujian kualitas perangkat lunak ISO/IEC 20510 dengan mengimplementasikan aspek pengujian perangkat lunak yakni functional suitability, performance efficiency, dan usability [9].

Tahap pengujian pertama pengujian functional suitability menggunakan kuesioner yang berisi daftar fungsi yang dimiliki aplikasi dan menggunakan metode penilaian ahli (expert judgement). Tahap pengujian kedua pengujian performance efficiency menggunakan pendekatan Automated Usability Testing Tools. Kinerja didasarkan pada beberapa parameter umum seperti: Performace, No of Requests, Speed, Load Time, Page Size. Pengujian parameter tersebut dapat diukur di antaranya dengan menggunakan tools GTMetrix. Tahap pengujian ketiga pengujian usability menggunakan instrumen berupa angket yang mengacu pada angket yang 
dikembangkan oleh Ardnol M Lund dalam [10]. Selain instrument tersebut terdapat pula instrumen analisis kebutuhan yang digunakan untuk mengetahui kebutuhan awal pengguna dalam membangun sistem yang dibuat.

\section{Analisis Data}

Analisis data yang digunakan dalam penelitian ini adalah analisis deskriptif kauntitatif. Data yang dianalisis barasal dari data persepsi dosen dan penilaian ahli yang diperoleh dari analisis angket. selanjutnya data mengenai performa sistem yang dibuat diperoleh dari hasil pengujian menggunakan tools GTmtrix.

Data yang didapatkan dari setiap instrumen akan dihitung rata-rata menggunakan rumus [11].

$$
\bar{x}=\frac{\sum x}{n}
$$

Dimana :

$$
\begin{array}{ll}
\bar{x} & =\text { skor rata-rata } \\
x & =\text { skor total item } \\
n & =\text { jumlah item }
\end{array}
$$

Sedangkan untuk menghitung skor persentase kelayakan menggunakan rumus [11],

Kelayakan $(\%)=\frac{\text { Skor yang diobservasi }}{\text { Skor yang diharapkan }} \times 100 \%$ (2)

Setelah data hasil berupa nilai deskriptif kuantitatif, nilai yang diperoleh dikonversi menjadi nilai kualitatif berskala 5 dengan Skala Likert. Konversi persentase ke pernyataan seperti dalam Tabel 1 berikut [12]:

TABEL 1. SKALA LIKERT

\begin{tabular}{cll}
\hline No & Persentase (\%) & Interpretasi \\
\hline 1 & $0-20$ & Sangat Tidak Layak \\
2 & $21-40$ & Tidak Layak \\
3 & $41-60$ & Cukup Layak \\
4 & $61-80$ & Layak \\
5 & $81-100$ & Sangat Layak \\
\hline
\end{tabular}

Pada pengujian functionality, pengukuran dilakukan oleh ahli pemprograman dengan rumus [11],

$$
X=1-\frac{A}{B}
$$

Dimana:

$$
\begin{array}{ll}
\mathrm{X} & =\text { Functionality } \\
\mathrm{A} & =\text { Jumlah total fungsi yang tidak valid } \\
\mathrm{B} & =\text { Jumlah seluruh fungsi }
\end{array}
$$

Berdasar rumus (3) tersebut, functionality dikatakan baik jika $X$ mendekati $1(0<=X<=1)$.

\section{HASIL DAN PEMBAHASAN}

Hasil dari penelitian ini adalah sebuah sistem informasi yang ditujukan untuk dosen dalam lingkup Jurusan Pendidikan Teknik Elektro Fakultas Teknik Universitas Negeri Makassar. Model pengembangan yang digunakan adalah model incremental dimana mengutamakan perhatian pada sistem requirement dan mengimplementasinya dalam team development. Pengembangan dilakukan dengan mengacu pada tahap - tahap yang telah dimungkinkan pada model incremental yaitu, (1) Requirement, (2) Specification, (3) Architecture Design, (4) Code, (5) Test.

\section{A. Analisis Kebutuhan}

Analisis kebutuhan dilakukan dengan pengumpulan informasi kepada calon pengguna dengan menggunakan angket. Bedasarkan hasil analisis kebutuhan yang telah dilakukan maka diperoleh data. Data tersebut dapat diuraikan dalam beberapa kriteria yaitu:

1. Semua dosen pada Jurusan Pendidikan Teknik Elektro telah mengetahui tentang Pedoman Penilaian Angka Kredit untuk kenaikan pangkat dan kenaikan jabatan fungsional dosen dan semua dosen juga menyetujui jika penyimpanan berkas untuk beban kerja dosen dibuat dengan bantuan teknologi informasi.

2. Untuk penyimpanan file yang berkaitan dengan beban kerja dosen dengan pemanfaatan teknologi informasi, sebanyak $57 \%$ dosen sudah melakukan sedangkan $43 \%$ masih menyimpan secara manual. Semantara itu sebanyak $60 \%$ dosen sudah tidak kebingungan untuk mencari file yang berkaitan dengan beban kerja dosen dan $40 \%$ masih kebingungan dalam mencari file.

3. Untuk dosen yang sudah menyimpan file sesuai dengan pembagian kriteria penilaian Angka kredit (membagi berdasarkan KUM) yaitu $73 \%$ dan sebanyak $27 \%$ dosen masih menyimpan file tidak sesuai dengan pembagian penilaian Angka Kredit. Selain itu persentase dosen yang sering kehilangan file yang berkaitan dengan beban kerja dosen masih cukup tinggi yaitu sebanyak $37 \%$.

4. Dalam hal memperoleh informasi tentang pengajuan kenaikan pangkat dan jabatan fungsional persentase ketidak tahuan dari hasil analisis yang dilakukan diperoleh angka yang sangat tinggi yaitu 57\%. Hal ini juga didukung oleh hasil analisis yang telah dilakukan pada kecukupan informasi yang diperoleh dosen mengenai capaian Tridharma perguruan tinggi yang telah dicapai. Berdasarkan data yang diperoleh sebanyak $83 \%$ dosen belum memperoleh informasi bahwa capaian Tridharma (pengajaran, penelitian, pengabdian, dan penunjang) sudah mencukupi atau tidak untuk kenaikan pangkat dan 
jabatan fungsional berdasarkan kriteria yang sudah tertuang dalam Pedoman Penilaian Angka Kredit.

5. Dalam hal informasi mengenai beban kerja dosen yang harus dipenuhi persemester, dosen belum memperoleh informasi yang cukup untuk menyimpulkan beban kerja sudah mencukupi atau tidak. Berdasarkan hasil analisis data yang dilakukan sebanyak $70 \%$ dosen tidak mengetahui bahwa apakah beban kerja yang menjadi target tercapai atau tidak, hanya $30 \%$ dosen yang mengetahui hal tersebut.

\section{B. Desain Sistem Informasi}

Desain Sistem merupakan tahap perancangan software yang dilakukan untuk perbagian yanga akan menjadi modul pada sistem informasi. Perancangan dimulai dari penentuan komponen sistem informasi, Data Flow Diagram, Antar Muka (Interface).

\section{Komponen Sistem Informasi}

Dalam penentuan komponen yang akan digunakan untuk membangun sistem informasi di Jurusan Pendidikan Teknik Elektro diambil dari hasil analisis kebutuhan yang dilakukan dengan pemberian angket. Berdasarkan hasil analisis diperoleh bahwa Dosen pada Jurusan Pendidikan Teknik Elektro sangat membutuhkan penyimpanan berkas berbasis online yang berhubungan dengan beban kerja dosen dan kenaikan pangkat. Komponen sistem informasi dapat dilihat pada Gambar 2.

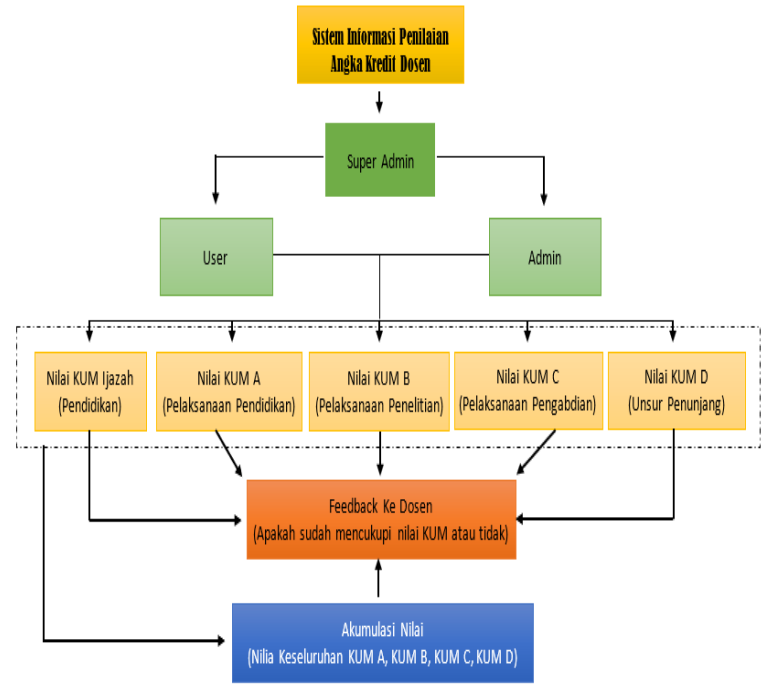

Gambar 2. Komponen Sistem Informasi

\section{Data Flow Diagram}

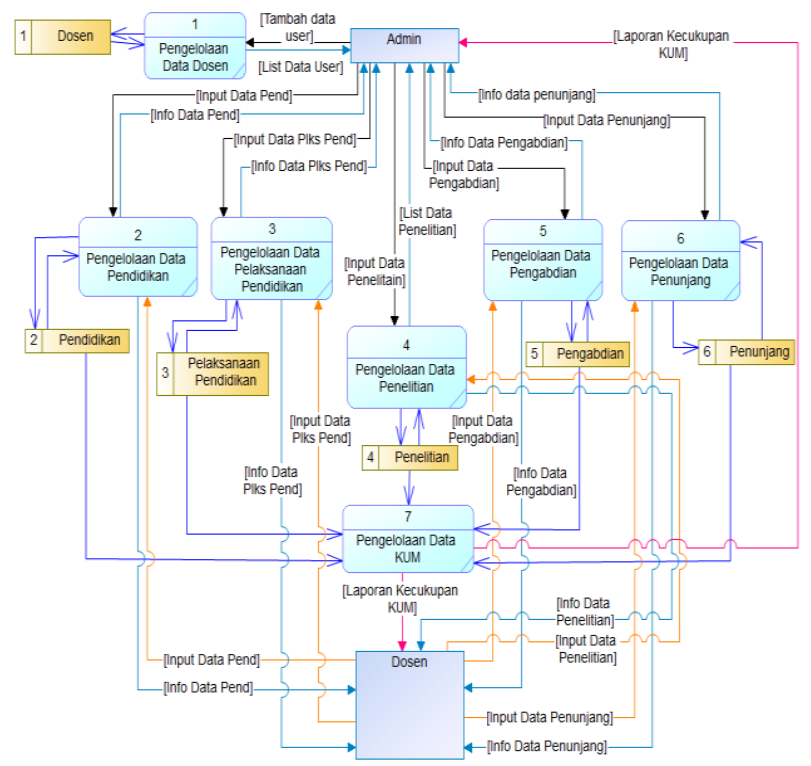

Gambar 3. DFD Level 1

Untuk perancangan arus data dalam sistem informasi Penilaian Angka Kredit Dosen Jurusan Pendidikan Teknik Elektro Universitas Negeri Makassar, Data Flow Diagram (DFD) banyak digunakan untuk perangkat lunak terstruktur [13]. Gambaran DFD pada sistem informasi yang dibuat dapat di lihat pada Gambar 3.

\section{Antar Muka (Interface)}

a) Tampilan Menu Administrator

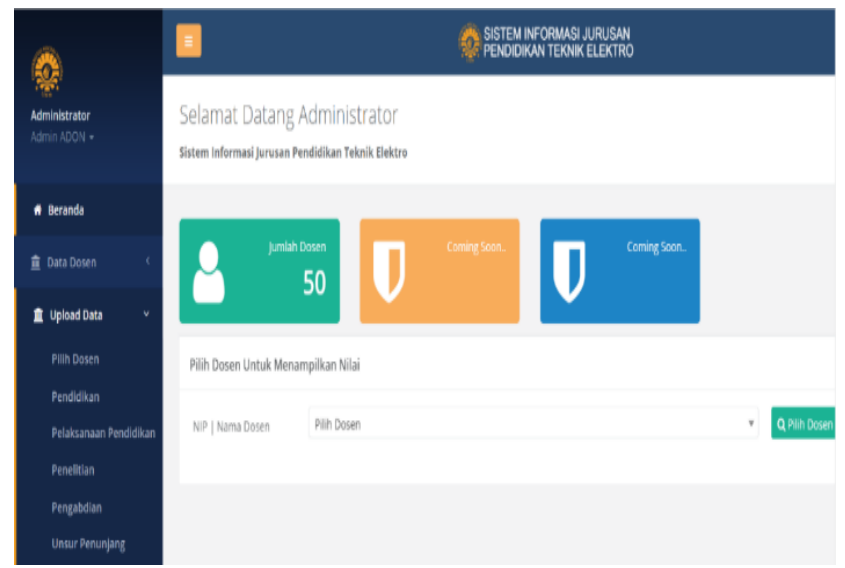

Gambar 4. Menu Administrator

Pada bagian admin, terdapat beberapa menu yaitu menu beranda, menu data dosen dan menu opload data dosen. Pada menu beranda, admin dapat melihat semua jumlah dan data dosen. Pada menu data dosen, admin mampu menambahkan dosen dan mengupdate data dosen. Sedangkan pada menu upload data, admin mampu mengupload data dosen berdasarkan kriteria file yang diberikan. 
b) Tampilan Menu User (Dosen)

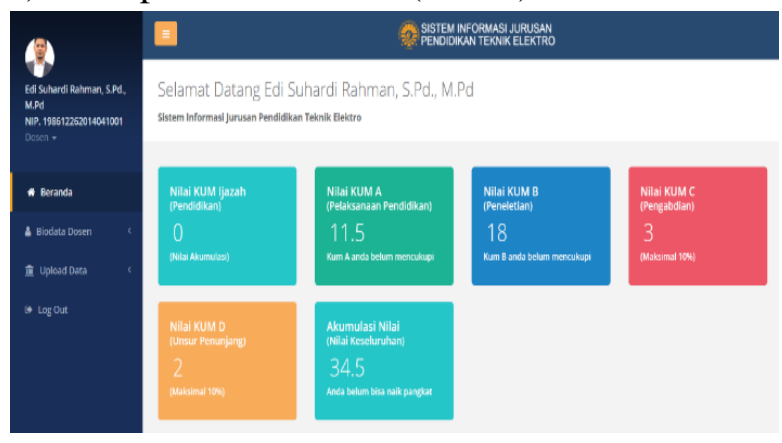

Gambar 5. Menu User (Dosen)

Pada bagian user (dosen), terdapat beberapa menu yaitu menu beranda, menu biodata dosen dan menu opload data dosen. Pada menu beranda, dosen dapat melihat feedback yang berkaitan dengan tridharma perguruan tinggi, selain itu dosen juga memperoleh informasi mengenai kelayakan untuk mengajukan kenaikan pangkat. Sedangkan pada menu upload data, dosen mampu mengupload data dosen berdasarkan kriteria file yang diberikan.

\section{Pengujian}

1. Pengujian Funcionality

Pengujian funcionatility dilakukan dengan menggunakan rumus (3) [11]. Berdasarkan hasil perhitungan maka didapatkan nilai functionality sebesar 1. Berdasarkan skor tersebut maka kualitas perangkat lunak dari sisi funcionalty dapat dikatakan "baik" sesuai dengan interprestasi ISO 20510 yaitu nilai yang baik adalah nilai yang mendekati 1 [11]. Berdasarkan hasil tersebut maka sistem informasi kenaikan pangkat dosen pada Jurusan Pendidikan Teknik Elektro layak digunakan untuk mendukung pengelolaan manajemen akademik dosen karena sistem tersebut telah lolos dalam uji funcionalty berdasarkan hasil uji.

\section{Pengujian Performance Efficiency}

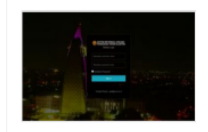

Latest Performance Report for: http://jpteunm.com/

Report genertated: Fi, Jan 8, 2021 10:57 PM-0800
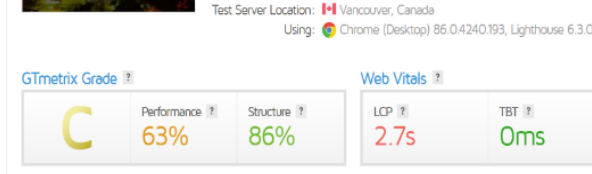

0

Gambar 6. Hasil Pengujian Sistem

Pengujian performance efficiency dilakukan dengan menggunakan koneksi internet dengan kecepatan download 56,28 Mbps dan upload 14,24 Mbp. Pengujian dilakukan dengan memasukkan alamat sistem portal pada address bar pada home page GTMetrix. Gambar 6 menunjukkan hasil pengujian Sistem Informasi dengan GTMetrix.

Berdasarkan hasil pengukuran dengan menggunakan tools GTmetrix, diperoleh nilai dari hasil pengukuran yaitu berada pada Grade $\mathrm{C}$ dengan nilai $63 \%$. Kriteria hasil penilan tersebut menujukkan bahwa sistem informasi yang dibuat masih memiliki masalah performa. Hal ini diakibatkan oleh beberapa masalah Optimize Image yang artinya mengoptimalkan ukuran gambar sehingga ukuran besar file gambar bisa menjadi lebih kecil dan Served Scaled Images menyajikan gambar yang sebenarnya sehingga kedua permasalahan ini memperlambat kinerja dari sistem informasi dan GTmetrix.

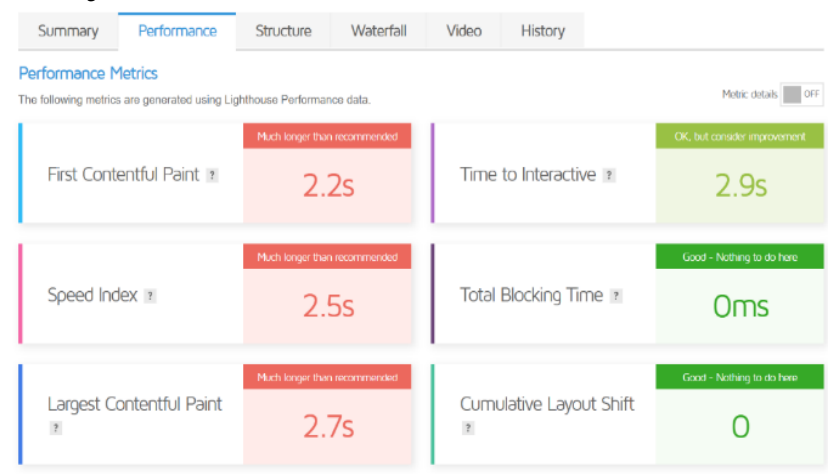

Gambar 7. Rekomendai perbaikan dari hasil pengujian pada GTmetrix

Pada hasil pengukuran yang dilakukan, GTmetrix juga memberikan rekomendari perbaikan dari hasil pengujian. Rokemdasi yang diberikan yaitu pada First Contentful Paint, Speed Index dan Largest Contentful Paint. Hal ini bisa di lihat pada Gambar 7 dari hasil pengujian GTmetrix.

\section{Pengujian Usability}

Pengukuran usability dilakukan dengan menggunakan rumus (2). Pengukuran usability yang dilakukan terdiri dari 4 aspek dengan menggunakan angket yaitu, Usefulness, Ease of Use, Ease of Learning dan Satisfaction. Hasil pengukuran ke empat aspek usability dapat di lihat pada Tabel 2.

\begin{tabular}{ccccc}
\multicolumn{5}{c}{ TABEL 2. HASIL PENGUKURAN USABILITY } \\
\hline No & $\begin{array}{c}\text { Asepek } \\
\text { Usabiliti }\end{array}$ & $\begin{array}{c}\text { Skor } \\
\text { Maksimal }\end{array}$ & $\begin{array}{c}\text { Skor } \\
\text { Responden }\end{array}$ & $\mathbf{( \% )}$ \\
\hline 1 & Usefulness & 1200 & 1002 & 83,5 \\
2 & Ease of Use & 1200 & 1010 & 84,5 \\
3 & Ease of & 600 & 516 & 86 \\
& Learning & & & \\
4 & Satisfaction & 1050 & 881 & 84 \\
& Total & $\mathbf{4 0 5 0}$ & $\mathbf{3 4 0 9}$ & $\mathbf{8 4 , 1}$ \\
\hline
\end{tabular}


Pengukuran usability dilakukan dengan menghitung persentase jawaban dari sejumlah responden. Skor yang diobservasi didapatkan dari jumlah skor total seluruh jawaban dari 30 responden, yaitu sebesar 3409, sedangkan skor yang diharapkan diperoleh dari jumlah skor maksimal skala dikalikan dengan jumlah pertanyaan kemudian dikalikan dengan jumlah responden yaitu sebesar 4050. Setelah diketahui hasil dari skor yang diobservasi dan skor yang diharapkan, maka diperoleh hasil pengukuran berdasarkan (2) yakni sebesar $84,1 \%$. Jika hasil tersebut dihubungkan dengan interpretasi skor pada Tabel 2 Nilai persentase kelayakan sebesar $84,1 \%$ berada pada interval 81 sampai $100 \%$ yang menunjukkan bahwa hasil pengukuran usability sistem informasi penilaian angka kredit yang digunakan di Jurusan Pendidikan Teknik Elektro memiliki nilai "sangat layak".

\section{SIMPULAN}

1. Pengembangan sistem informasi penilaian angka kredit dosen pada Jurusan Pendidikan Teknik Elektro dikembangkan menggunakan model pengembangan perangkat lunak Waterfall yang terdiri dari (1) Analisis kebutuhan, (2) Perencanaan,

Pengembangan/pengkodean sistem, dan (4) Implementasi/pengujian sistem. Sistem ini memiliki tiga pengguna yaitu super admin, admin, dosen dengan fitur sesuai dengan hak akses yang dimiliki. Sistem ini memberikan informasi mengenai penialaian tridharma perguruan tinggi bagi dosen sehingga memudahkan dosen dalam melakukan manejemen kenaikan pangkat dan kenaikan jabatan fungsional.

2. Pengembangan sistem informasi penilaian angka kredit dosen pada Jurusan Pendidikan Teknik Elektro yang dihasilkan berada pada kategori sangat valid, sehingga layak digunakan untuk tahapan uji coba lapangan oleh pengguna. Kemudahan sistem informasi penilaian angka kredit dosen pada tahapan uji coba lapangan berada pada kategori sangat layak, menunjukkan bahwa sistem informasi sangat mudah dipahami dan layak digunakan oleh pengguna.

\section{DAFTAR PUSTAKA}

[1] W. A. Triyanto, "Android-Based Lecturer Workload Simulation Application," in Journal of Physics: Conference Series, 2020, vol. 1430, no. 1, p. 012050.
[2] B. A. Minartiningtyas and I. K. A. Sumariata, "Rancang bangun sistem informasi perhitungan angka kredit dosen stmik stikom indonesia," SINTECH (Science and Information Technology) Journal, vol. 1, no. 1, pp. 41-50, 2018.

[3] M. Jannah, "Sistem informasi berorientasi objek untuk kenaikan pangkat dosen," Universitas Islam Negeri Maulana Malik Ibrahim, 2013.

[4] H. Hartini and F. Tan, "Sistem Pendukung Keputusan Kenaikan Jabatan Fungsional dan Pangkat Dosen," Jurnal Sisfokom (Sistem Informasi dan Komputer), vol. 7, no. 1, pp. 3844, 2018.

[5] M. I. P. Nasution, "Pedoman Operasional Penilaian Angka Kredit Kenaikan Jabatan Akademik/Pangkat Dosen".

[6] W. W. Royce, "Managing the Development of Large Software Systems 1970," in Proceedings, IEEE WESCON, 2012, pp. 1-9.

[7] Y. Bassil, "A simulation model for the waterfall software development life cycle," arXiv preprint arXiv:1205.6904, 2012.

[8] R. D. Jayanto, "Evaluasi Kualitas Aplikasi Mobile Kamus Istilah Jaringan Pada Platform Android dengan Standar ISO/IEC 25010," Elinvo (Electronics, Informatics, and Vocational Education), vol. 2, no. 2, pp. 178-182, 2017.

[9] A. B. David, "Mobile Aplication Testing (Best Practices to Ensure Quality)," AMDOCS. Retrieved May, vol. 25, p. 2014, 2011.

[10]E. S. Rahman and D. Vitalocca, "Analisis Usabilitas Menggunakan Use Questionnaire Pada Sistem Informasi Smk Negeri 3 Makassar," Jurnal MEKOM (Media Komunikasi Pendidikan Kejuruan), vol. 5, no. 1, pp. 16-22, 2019.

[11]T. N. Sari, "Analisis kualitas dan pengembangan sistem informasi akademik berbasis web menggunakan standard iso 9126," JIKO (Jurnal Informatika dan Komputer), vol. 1, no. 1, 2016.

[12]Riduwan and Akdon, Rumus dan Data dalam Analisis Statistika. Bandung: Alfabeta, 2008.

[13]Q. Li and Y.-L. Chen, "Data flow diagram," in Modeling and Analysis of Enterprise and Information Systems, Springer, 2009, pp. 85-97. 